UDC 316.77:351

JEL: L81, L86, G11, G23, G41

\author{
Mariana Makarova \\ Doctor of Economic Sciences, \\ Professor, Leading Researcher, \\ International Research and Training \\ Center for Information Technologies \\ and Systems of the National \\ Academy of Sciences of Ukraine and \\ Ministry of Education and Science of \\ Ukraine \\ Kiev, Ukraine \\ E-mail:makarowa45@gmail.com \\ orcid.org/ 0000-0002-9225-933X
}

Received: September, 2018

Accepted: October, 2018

DOI:10.31520/2616-7107/2018.2.3-4

(C) Economics. Ecology. Socium, 2018 CC BY-NC 4.0 license

\section{THE INFLUENCE OF BITCOIN ECOSYSTEM ON DIGITAL ECONOMY}

Introduction. Bitcoin is a digital, decentralized, partially anonymous currency, not supported by any government or legal entity and not provided with gold or other goods. It relies on a peerto-peer network and cryptography to maintain its integrity. The proponents claim that Bitcoin has many properties that could make it an ideal currency for consumers and merchants in a modern digital economy.

Aim and tasks. The purpose of article was to determine and analyze impact of Bitcoin ecosystem on global digital economy. The research objectives were as follows: to specify the concept of Bitcoin ecosystem; to study the trends and prospects of cryptocurrencies development; to determine the role of Bitcoin as an alternative mean of preserving capital for investors - «gold bugs»; to compare the influence of gold and Bitcoin on development of a world financial system; to study the importance of Bitcoin and gold as financial assets of digital economy and the role of Bitcoin as a financial instrument inherent in this economy.

Research results. The concept of Bitcoin ecosystem, its main components, factors and risks of development in historical and logical aspects are considered. The tendencies and prospects of cryptocurrencies development, particullary Bitcoin, their influence on traditional E-commerce, conduction of micro-payments, calculations in a field of virtual games are investigated. The role of Bitcoin as an alternative mean of capital preservation for a certain type of investors is determined. The comparative analysis of an influence of gold and Bitcoin on development of world financial system in historical aspect has been carried out. The conclusions are made about role of cryptocurrency (bitcoin) and gold as financial assets of digital economy. The role of Bitcoin as a financial tool corresponding to service requirements of actors of digital economy is determined.

Conclusion. In last few years in many countries the largescale Bitcoin-ecosystem and economy has developed with tens of millions of Bitcoins which daily change owners in electronic transactions. These funds still have a small amount relative to the rest of world's trading assets and economy.

Today, while the digital currencies work in the semi-legal field in most countries, they may be a danger to national securities laws, be an instrument for tax evasion, illegal banking, money laundering, illicit drug trafficking, etc. This ability should be considered as one of the most unsafe risks of the functioning for Bitcoin ecosystem.

But this is just the beginning of transformations for globalized system, since both society, economy and finance will become fully digital. The problem now is how to find right application for cryptocurrency, so that it becomes a paradigm of financial trust for humanity, as was previously with gold.

Key words: cryptocurrencies, fiat currencies, gold, bitcoin (BTC), blockchain, digital economy. 


\section{УДК 316.77:351}

\section{JEL: L81, L86, G11, G23, G41}

\section{Маріана Макарова}

Доктор економічних наук, професор, провідний науковий співробітник

Міжнародний науково-навчальний центр інформаційних технологій та систем НАН України та МОН України

Київ, Україна

E-mail: makarowa45@gmail.com orcid.org/ 0000-0002-9225-933X

Отримано: Вересень, 2018

Прийнято: Жовтень, 2018

DOI: $10.31520 / 2616-7107 / 2018.2 .3-4$

(C) Економіка. Екологія. Соціум, 2018 CCBY-NC 4.0 ліцензія

\section{ВПЛИВ ЕКОСИСТЕМИ БІТКОІНА НА ЦИФРОВУ ЕКОНОМІКУ}

Проблема. Біткоін - цифрова, децентралізована, частково анонімна валюта, що не підтримується будь-яким урядом або юридичною особою i не забезпечена золотом або іншими товарами. Вона спирається на пірингову мережу та криптографію для підтримки своєї цілісності. Постає питання обгрунтування біткоїну як ідеальної валюти для споживачів i торговців у сучасній цифровій економіці.

Мета та завдання. Метою статті було визначити i проаналізувати вплив екосистеми біткоіна на світову цифрову економіку. Завдання дослідження полягали у такому: конкретизувати поняття екосистеми біткоіна; дослідити тенденції та перспективи розвитку криптовалют; визначити роль біткоіна як альтернативного засобу збереження капіталу для інвесторів; порівняти вплив золота і біткоіна на розвиток світової фінансової системи; дослідити значення біткоіна i золота в якості фінансових активів цифрової економіки і роль біткоіна як фінансового інструменту, іманентного цій економіці.

Результати. Розглянуто поняття екосистеми біткоіна, ii основні складові та фактори і ризики розвитку в історичному i логічному аспектах. Досліджено тенденції та перспективи розвитку криптовалют, зокрема, біткоіна, його вплив на традиційну електронну комерцію, проведення мікроплатежів, розрахунків у сфері віртуальних ігор. Визначено роль біткоіна як альтернативного засобу збереження капіталу для певного типу інвесторів. Проведено порівняльний аналіз впливу золота i біткоіна на розвиток світової фінансової системи в історичному аспекті. Зроблено висновки щодо ролі криптовалют (біткоіна) i золота як фінансових активів цифрової економіки. Визначено роль біткоіна як фінансового інструменту, відповідного вимогам обслуговування суб'єктів цифрової економіки.

Висновки. В останні кілька років у багатьох країнах розвинулася широкомасштабна біткоін-екосистема й економіка 3 десятками мільйонів біткоінів, які щоденно змінюють власників у електронних транзакціях. Ці грошові засоби мають поки невеликий обсяг відносно решти світових торговельних активів та економіки. Сьогодні поки цифрові валюти у більшості країн працюють у напівлегальній правовій сфері, бо можуть виступати певною небезпекою для національних законів про цінні папери, бути влучним знаряддям для ухилення від сплати податків, проведення неправової банківської діяльності, «відмивання» незаконно отриманих грошей, торгівлі нелегальними наркотиками тощо. Цю здатність слід розглядати як один 3 найбезпечніших ризиків функціонування екосистеми біткоіна. Але це тільки початок трансформацій для глобалізованої системи, оскільки і суспільство, й економіка, i фінанси стануть повністю цифровими, що потребує вірне застосування для криптовалюти, щоб вона стала для людства парадигмою фінансової довіри, як це набагато раніше відбулося із золотом.

Ключові слова: криптовалюти, фіатні валюти, золото, біткоін (BTC), блокчейн, цифрова економіка. 
Research problem statement. Bitcoin (BTC) is a digital, decentralized, partially anonymous currency that is not supported by any government or legal entity and is not provided with gold or other commodities. It relies on a peer-to-peer network and cryptography to maintain its integrity. Proponents claim that bitcoin has many properties that can make it the ideal currency for consumers and traders in the modern digital economy. Thus, bitcoin is a highly liquid financial means, has low transaction costs, is used to send fast payments via Internet and can be used for micro payments.

Despite the fact that the crypto exchange economy is developing, users are now concerned about the legal status of BTC and other cryptocurrencies (altcoins) and the controversial government intentions regarding them - from the total prohibition of cryptocurrency exchange activity to the recognition of cryptocurrencies with equal payment facilities, along with national currencies.

Analysis of research problems. Cryptocurrency as a financial asset and a factor of serious impact on digital economy, and not just the implementation of the blockchain technology, began to be considered by researchers in the past 5-6 years. Here we can mention the works of $\mathrm{H}$. Biloglazova [1], P. Vinia, M. Keisi [2], Ch. Hudkhard, M. Kriuher-Sharle, V. Mishchenko [3], R. Grinberg [5], D. Guarda [6] and others.

Highlighting unresolved issues. For less than a decade of bitcoin's functioning, of course, the main ideas of researchers concerning the factors of the cryptocurrency market development in the modern digital economy, terminology of the problem have not been formed yet. Thus, the question of the real impact of bitcoin as a means of payment on traditional e-commerce, micro payments, calculations in the field of virtual games has not actually been considered by domestic researchers. Another less interesting aspect is the determination of the bitcoin role as an alternative means of preserving capital for a certain type of investor, so-called "golden beetles". Comparison of the gold and bitcoin impact on the development of the world financial system has not found sufficient coverage in the scientific literature yet.

The purpose of the article is to identify and analyze the impact of bitcoin ecosystem on the global digital economy.

Presentation of the basic material and substantiation of the research results.

Growing ecosystems that surround bitcoin and altcoin include transactions themselves, transaction service providers, market information providers and charts, institutions serving cryptocurrency deposits, mergers of various virtual currencies, and so on.

Today, the futures market is already in the BTC-ecosystem (since December 2017), however, while there are no actors offering legal revenues from crypto currency investments, such as small reserve banks, although individual owners of private business announce their intentions to do that. Here we should mention the dynamic distribution of ICO and ITO cryptocurrency projects [2].

Individuals who possess cryptocurrency are represented by a number of stakeholders from pioneers of blockchain technology, enthusiasts of information security and cryptography, to speculators, investors who do not trust governments and even criminals.

A large number of online merchants, including Web-hosts, online casinos, the illicit drug market, auction sites, technological consulting firms, media for adults, etc., take bitcoins to serve their owners. However, unfortunately, while hosting crypto currency from consumers, we see little the representatives of the retail online trading business, although the growing trend is observed here.

Several specific exchanges have been established to meet the demand for crypto currency, the most well-known and most reputable of which are BitFinex, Binance, which are among the top ten in terms of sales of bitcoins, etc. (Fig. 1). Crypto currency exchanges offer the exchange of traditional currencies, including US dollars, Japanese yen, euros and others, on bitcoins and altcoins and vice versa. 
Today, while digital currencies in most countries work in a semi-legal area, they may be a danger for national laws regarding securities, be an instrument for tax evasion, illegal banking, money-laundering, illicit trafficking, and child pornography. Clearly, this ability should be considered as one of the safest risks of the bitcoin ecosystem functioning.

Thus, bitcoin is similar to dozens of other digital currencies, because it is a digital medium that is convenient for end users, it can be exchanged for other digital and fiat assets, anonymous, etc. (Fiat money are those that are not provided with gold and other precious metals, the nominal value of which is established and guaranteed by the state, regardless of the material cost used for their manufacture. They are usually irreplaceable on gold or silver).

However, bitcoin has several main features: in its ecosystem, there is no centralized authority that can issue a new amount of currency or to deceive its owners (for example, keeping partial reserves when it was promised to keep it full); it's fiat, not commodity money; difficult to regulate, because there is no centralized control body; Algorithmic identification of its miners is functioning successfully; it provides a potential general anonymity in electronic transactions.

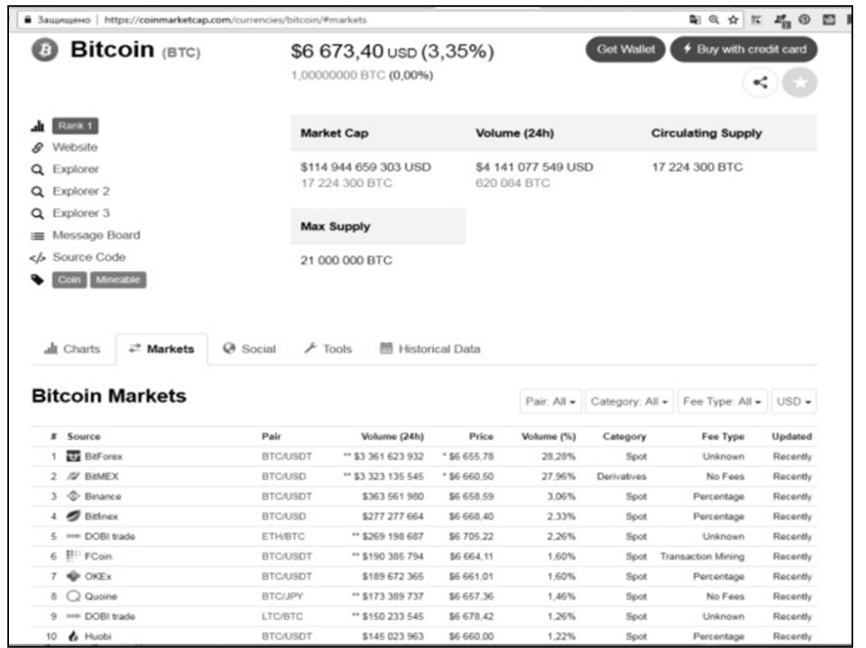

Fig. 1. List of crypto currency exchanges from the top ten in terms of bitcoin trading (as of August 2018)

*According to the site https://coinmarketcap.com)
Today, bitcoin and altcoin have the potential to become significant players on the market of micropayments and in the world's virtual trading systems, computer games. In addition, they can allow organizations, opposition governments, etc., to finance, without risking the withdrawal of their funds or sanctions against their financial contributors.

In our opinion, although bitcoin and altcoin, despite the need of commodities and lack of direct support by government agencies, can succeed, potential users and investors must be aware, of course, of all the risks associated with the use of such a young financial and information technology as a blockchain.

Let's consider the competitive advantages of bitcoin in detail compared with two classes of products - those that serve the conduction of e-commerce, and currencies for which the provision of gold is declared. Is it unlikely that bitcoin and alternative digital currency can establish significant competition with electronic payment systems operating at the traditional ecommerce market, since consumers here do not care about such anonymity that provides bitcoin, and prefer to compare prices for goods and services in currency, which they use most, and are more likely to seek protection from fraud, which is currently lacking in digital currency such as bitcoin [5].

However bitcoin can be particularly competitive at the market of micro payments and in virtual global markets where consumers are less concerned about pricing in a familiar currency. Bitcoin can be appealing to those who enjoy hard currency, provided with gold, because its value depends on the presence of a limited, albeit virtual resource and not voluntarist acts of central banks, such investors are called "gold beetles" [2].

It is well known that the growth of the Internet has created demand for electronic payment systems. PayPal and other similar systems allow users to spill online orders using credit card or bank transfer. However, bitcoin is unlikely to be particularly competitive at the traditional e-commerce markets, as most consumers are not concerned about anonymity or decentralization: they do not want to buy real products at prices set in bitcoins instead of dollars or other common currency. Bitcoin has 
no built-in anti-fraud capabilities, while PayPal Company has invested millions of dollars in fraud protection. However, bitcoin and other digital currency have one of the significant benefits - low transaction costs. However, if the proportion of online use by consumers of credit cards continues to decline, there is no reason to think that e-payment system leaders such as PayPal will not reduce their transaction costs in response to competitive pressure from bitcoin [5].

One of the varieties of e-commerce is served by very small payments, so-called micro payments, for example, when paying for digital goods. Because sometimes the transaction costs through the existing Internet payment processing systems exceed the size of the payment itself by three times, that is, the payment, say, 10 hryvnias is converted into 40 hryvnias, it is impractical to conduct it through the Network. Bitcoin can be competitive in this space due to the low transaction costs.

In addition to traditional e-commerce and micro-payments, individuals often also trade in "virtual gaming worlds", for example, buying or selling digital weapons in strategic games, and so on. While alternative digital currencies have failed to gain leadership in the world of traditional e-commerce, they are thriving in gaming e-commerce. Currency-related computer games have significant potential for earning revenue from their issuers, but, on the other hand, the establishment and maintenance of a secure virtual gaming counterfeit currency requires significant investment for technical and legal expertise, not to mention time costs. Such game currencies are also related to the problems of centralized control over them by game owners. Since bitcoin is capable of alleviating or eliminating some of these problems, it has the potential to become de facto standard for certain virtual and gamerelated currencies [5].

Some businessmen and investors are interested in crypto currency because of their political beliefs and personal investment forecasts. They believe that central bank institutions that have the right to print more money, such as the US Federal Reserve, corrupt the economy, contribute to inflation, and therefore they do not trust the currencies supported by the state. Accordingly, these individuals prefer to keep their wealth and make exchanges in currencies provided by goods, usually in gold. In the West they are called "golden beetles" [2, 5].

An analysis of this trend compared with bitcoin is instructive. Historically, many currencies were valuable by their nature (gold or silver coins). To facilitate the transport of heavy coins, some governments, banks or private companies have founded paper money that can be redeemed for a certain amount of gold or other commodity. In other cases, some governments have established paper currencies that are not covered by goods. These fiat currencies were of value simply because their support by governments identified them as legitimate. These governments could and did it, of course, to print out more currency over time, increasing its supply with respect to demand, which reduced the value of currency and consequently increased the prices of goods, that is, contributed to inflation. As mentioned above, crypto currencies have been massively established in the last decade by certain private technology companies, some for facilitating ecommerce, as discussed above, and others for serving the needs of "distrustful" investors.

Let's note that although the capitalization of the bitcoin economy is now about $\$ 111$ billion (as of August 2018), and in December 2017 it was almost three times as high - \$333 billion. (Fig. 2), questions still remain to it. Of course, this cost is symbolic, but all the money is symbolic. There are various ways to measure this volume of market capitalization of bitcoin. You can increase significantly this estimate if you consider all related ecosystems cryptocurrency relationships, especially now when blockchain is the core technology for banks and businesses.

Gold has existed for thousands of years and is measured in real forms by weight, and its preciousness is widely known. Bitcoin, like any currency, is an abstract form of money and can be measured only in units relative to itself. It should be remembered that it can become a fiat asset or a measure of sustainable value. Despite bitcoin's aggressive price action in 2017, there were observed and are observed periods of high volatility of its price, which should be taken very seriously. While the size and depth of the 
crypto currency foreign market is overshadowed by indicators of the gold market, which is estimated at 7 trillion dollars, that is, the latter is 22 times more [4].

Thus, bitcoin is still a small part of the global financial system, and its audience coverage, and its cost is very low, especially if you do not take into account the excitement caused by the speculative increase in its price at the end of 2017. Unlike ordinary currencies, there are evolutionary stages for any new form of money. Bitcoin cannot simply be printed, it is managed by digital forms and based on processing of algorithms, and nevertheless, it imitates many of the drawbacks of the properties of commodity gold in that it requires huge efforts and energy to create one coin. The deficiency and special energy of conservation of values is what defines gold and allows it to maintain its purchasing power during incomparably longer periods of time in the history of money.

Historically, the format of money has changed several times, especially many ups and downs occurred with national currencies. Crypto currency and bitcoin itself, possess partly the same properties of gold with the preservation of values that make gold historically dominant over fiat currency. The BTC, like gold, is also a global currency, which may be common in the future because of its digital nature. Even large global currencies such as USD, GBP or EUR cannot meet this requirement [5].

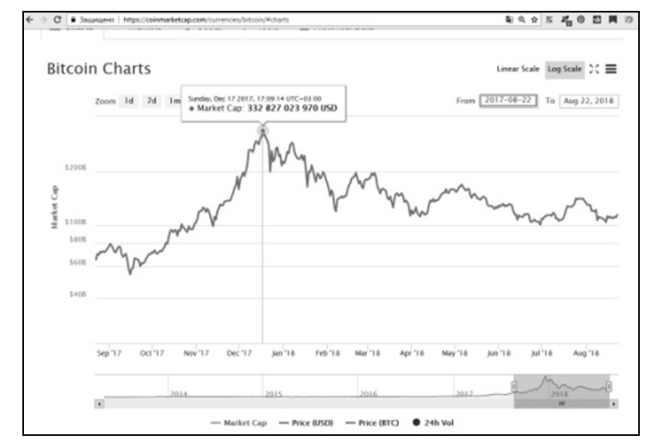

Fig. 2. Capitalization of bitcoin as of September 2017 - August 2018

*According to the site https://coinmarketcap.com

Bitcoin from time to time was the focus of attention due to its innovative radical concept, its high-ranking investors, the "good" or "bad" media attention to itself and, after all, because in 2017 it for the first time really exceeded the price of gold at a number of global crypto exchanges [5]. However, there is another important situation and a serious obstacle when comparing bitcoin and gold: the lack of regulation and certification of the first one, as well as the volatility of which the bitcoin price suffers (Fig. 3).

Gold and silver can be measured by weight in ounces, grams, kilograms. Fiat currencies or any other abstract product or money, including bitcoin, cannot be measured in this way. The abstract can be measured only in units. Thus, gold and silver are the only form of money traded in weight. Fiat currency, on the other hand, cannot be measured by anything other than other currency; at least since the abolition of binding of the US dollar to gold in 1971 was canceled. In this regard, bitcoin belongs to the same category [6].

Gold is easy to track because it has a global tracking system. This helps to save the value of the investment, since fake, theft or mistake in shipping is complicated. Unfortunately, the same cannot be said about bitcoin. In fact, the second significant "crash" at the bitcoin market occurred in 2014 due to the theft of millions of dollars by hackers at one of the biggest cryptocurrency exchanges MT.GOX at that time due to a defect in its software [4]

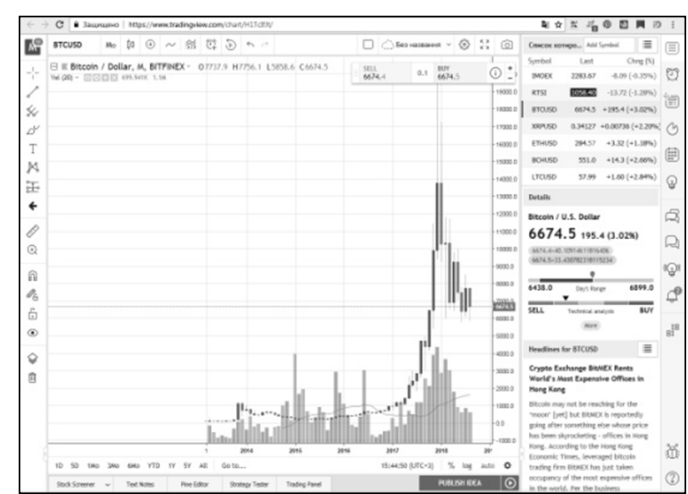

Fig. 3. Price fluctuations of bitcoin in the period of 2013-2018

*According to the site https://ru.tradingview.com 
Moreover, it is impossible to follow the bitcoins, since they were originally intended to evade state authorities. Whether you refuse to pay taxes or try to finance activities that are not worth financing, for this bitcoin will fit perfectly, as already mentioned above. It should be remembered that this could be a serious limitation for bitcoins in the event that global governments decide finally to regulate functioning of crypto currencies.

There is no doubt that gold is a rarity, but since we are moving towards a digital economy, bitcoin is even more rare, its rarity is laid down in its digital algorithm, although there are many questions left to it, no answers yet. While gold is the main primary goods that has historically been traded, bitcoin is, in a sense, an extension of digital gold, even more rarely because of its blockchain technology, and especially because it can only be set up in a strictly limited number [4].

Bitcoin's main software will stop its "extraction" beyond this limitation, and this will affect the price increase. This is important to understand, because if the supply is limited, and demand is high, the price increases. This is the basic principle of the economy. On the other hand, the price of gold also varies in demand and supply cycles, where high demand for gold prompts mining companies to seek new sources of gold. Moreover, in the case when gold costs quite expensive, people around the world make their gold jewelry and coins in cash. Many of these items are molten to create pure physical gold.

Gold has a steady global network of exchanges, while crypto exchange is still in its infancy and in an unstable transition process. Bitcoin suffers from instability, as in previous times, when the price fell sharply due to the situation with the MT.GOX exchange in 2014, and now, when a crisis of confidence in the "overheated" by speculators crypto currency market merged in early 2018. These incidents caused a lot of negative reviews on bitcoin in the press, but also led to greater public awareness. When events of this magnitude occur, this has serious consequences, for example, setting up a large discrepancy with the investment instruments traded at those exchanges. On the other hand, gold also has historical experience of ups and downs, but much more even in the long run. Gold had not such problems with the exchanges, although it faces price volatility (Fig. 4).

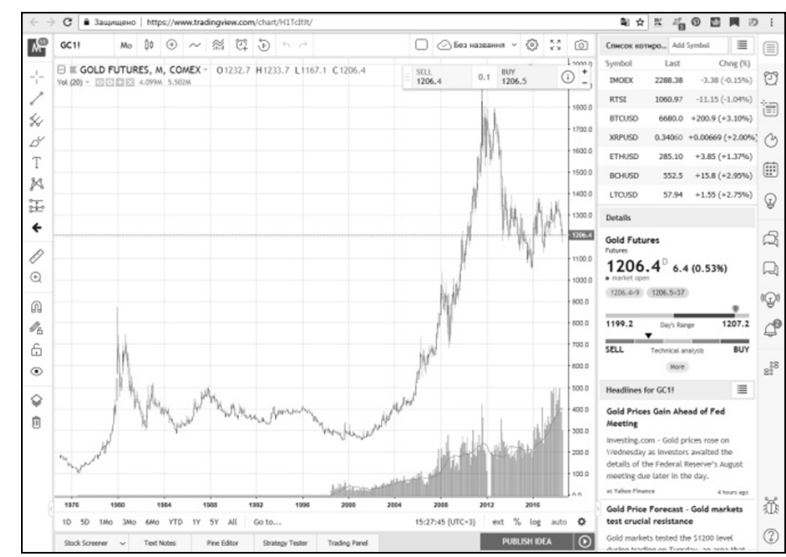

Fig. 4. Fluctuations in prices of futures for gold in the period 1976-2018.

*According to the site https://ru.tradingview.com

The global network of gold exchanges is historically transparent, thanks to clear and stable price signals. On the other hand, bitcoin is not so transparent due to its modernity, decentralization, non-regulation, and the base on digital technology. As already noted, there are really a few serious crypto exchanges that are different from each other. However, as the global economy is increasingly digitized, new opportunities are opening up as new global organizations and investors are looking for new solutions. There is no doubt that gold as the main trading unit has a solid base value, but on the other hand, although bitcoin is now partly a speculative financial asset, it provides and opens up new opportunities for the digital economy.

The most interesting investment in classical commodity gold is that there will always be a large, even industrial demand for it in terms of basic needs and its historical value in such areas as the manufacture of jewelry and works of art. In other words, gold has a basic value. Its price cannot fall below a certain level; otherwise it would affect the basic needs of mankind [6].

It should also be compared with the fact that gold is historically regarded as a traditional means of preserving values, because it can be 
used in unstable economic times, and, moreover, it is material. This cannot be said about bitcoin, it is "imaginary", digital, it has no industrial use - it's just an algorithm created on the basis of a digital symbolic code. It exists only on the Internet, in the form of code and information repositories on hard disks and servers. That is why it is important to pay attention to various aspects of the existence of bitcoin ecosystem. Gold has a universal value all over the world, which makes it as a commodity so special. People all over the world want to have gold. However, the same cannot be said about crypto currency. Certain investors and traders are interested in it. This is an important point in analyzing the main aspects of bitcoin functioning in comparison with gold functioning.

Bitcoin and gold comparison may seem incorrect, but in the end the first one is symbolic, and the second one is an officially approved social value. Do not forget that gold is a metal that can be found in nature. Gold has a historic reserve of value and is recognized throughout the world. Given the evolution of humanity and its changes throughout history, it makes sense to think about the evolution of money and financial value. The latest attention and the gigantic growth of the market price of bitcoin demonstrate the evolutionary side of the idea of money. And the analysis of these two issues is more than justifiable and critical for understanding new social and financial investments and trade paradigms [6].

Investors at different times may be afraid or, conversely, want to invest in bitcoin. As in any currency, he has ups and downs (see Fig. 3 ). By the way, one cannot pay attention to a certain price correlation for gold and bitcoin according to the graphs given in Figures 3 and 4 in the period 2014-2018. Investors should always take into account the above factors and considerations because in investing and trading it is necessary understand deeply the full risk of these operations and many legal nuances of bitcoin ecosystem functioning. While bitcoin is a currency based on developing algorithmic technology and has, without a doubt, a host of significant innovation features, there are still many questions and reservations about this financial instrument and, of course, risks. Analyzing bitcoin as an investment in comparison with gold, any trader and investor should be careful.

There is no doubt that gold still remains the only global metal mega commodity variety of currencies. Gold is also a commodity and a financial asset, which has shown itself as a means of preserving values for thousands of years, in different societies and civilizations, even taking into account the ups and downs in its assessment [6].

Thus, gold is a classic investment and it is easier to convert it into cash, however, bitcoin represents a new digital paradigm of the future, and that is exactly what is interesting. Conclusions and suggestions. The differences between gold and bitcoin are numerous, and humanity is only at the very beginning of the path, but in the new digital blockchain economy, strong and weak features of each side will be revealed. In the world of finance and investment, there is a large-scale financial revolution, and money is becoming quite digital. Crypto currencies, such as bitcoin and other significant altcoins, such as the ether, will become fiat. It's just about time [2].

The world works in a changing evolutionary environment, where there is a moving balance between ideas, technologies, shifts in financial engineering, innovation. The last hundred years have been the most dynamic in the history of the mankind, the evolution of money was particularly radical, complete collapse and volatility, along with financial innovations. The last ten years have been, and the next ten years will be more and more devastating and radical.

Blockchain technologies and the prospects for the development of all decentralized and distributed registries together with the critical number of technological innovations have the potential to liberate capital markets from some outdated operating players and begin the process of real rather than phoney, the formation of liquidity is separated from traditional market makers and investment banks in the direction to the infrastructure of the market itself, which establishes a more sustainable economy and a trade ecosystem. 
Here bitcoin plays the role of a leading representative, the first driving force of this revolution, but much still needs to be done in the development of blockchain technologies, the regulation of cryptocurrency, and so on.

Blockchain technology is capable of reducing the cost of global financial services over the next few years by hundreds of billions of dollars. Together with it, other technologies, such as artificial intelligence and the Internet are changing now everything that is known about the essence of the financial industry and the establishment of value [6].

If everything becomes digital in the society and the economy, you need both digital money and trading operations. But traditional primary goods and steady trust in the establishment of values when it comes to money and all forms of provision will remain for the mankind.

Gold and bitcoin relate to evolutionary systems in the history of money and finance. Gold has a historic, powerful track record; it's much more than just a commodity. It is a powerful metal used in the form of objects from jewelry to artwork and other applications, such as investments, etc.
Bitcoin, on the other hand, is a digital cryptocurrency with several years of life. Therefore, it has its own problems when it comes to a stable paradigm of commodity or monetary values. As the world evolves towards a digital economy, fully managed by artificial intelligence and blockchain, as well as financial digital technology, humanity will increasingly need new solutions, such as cryptocurrencies.

Today, especially in the last few years, in many countries a large-scale bitcoin ecosystem and economy with dozens of millions of bitcoins have developed which change the owners daily in electronic transactions spent on anything from electronics to web hosting, charity, purchases of organic products. These funds still have a small amount relative to the rest of the world's trading assets and the economy [6].

But this is just the beginning of transformations for the globalized system, since society, economy and finance will become fully digital. The problem now is how to find the right application for cryptocurrency, so that it becomes a paradigm of financial trust for humanity, as was previously the case with gold.

\section{REFERENCES}

1. Beloglazova, G.N., \& Kievich, A.V. (2011). The Modernization of Financial System Regulation: Search for New Models. Bankovskoe delo. 7. 14-20 [in Russian].

2. Vin'ja, P., \& Kejsi, M. (2017). The Age of Cryptocurrency: How Bitcoin and The Blockchain Are Challenging the Global Economic Order Paperback. Moskva: Mann, Ivanov i Ferber. [in Russian].

3. Mishhenko, V.I., Naumenkova, S.V., \& Ljon, I.M. (2017) The World Trends in Monetization of An Economy. Finansy Ukrajiny. 9. 53-74. [in Ukrainian].

4. Arzhevitin, S.M. (Ed.) (2018). The New Forms of Money and Financial Assets: Formation, Prospects, Risks. Kyjiv: KNEU.

5. Grinberg, R. (2011). Bitcoin: An Innovative Alternative Digital Currency. Hastings Science \& Technology Law Journal, 4. 160-207.

6. Guarda, D. (2017, March 22). Gold or Bitcoin and The New Digital Blockchain Economy? tradersdna.com. Retrieved from https://www.tradersdna.com/opinion/gold-versus-bitcoin-newdigital-blockchain-economy/.

7. Chuen, D.L.K., \& Deng, R. (2017) Handbook of Blockchain, Digital Finance and Inclusion. Cryptocurrency, FinTech, InsurTech, Regulation, ChinaTech, Mobile Security. New York:Academic Press.

8. Dodgson, M., Gann, D., \& Wladawsky-Berger, I. et al. (2015). Managing Digital Money. Academy of Management Journal. VOL. 58, NO. 2. 325-333. 


\section{ЛІТЕРАТУРА}

1. Белоглазова Г.Н. \& Киевич А.В. Модернизация регулирования финансовых систем: поиск новых моделей, Банковское дело. 2011. Вип.7, 14-20.

2. Винья П. \& Кейси М. Эпоха криптовалют. Как биткойн и блокчейн меняют мировой экономический порядок 2017.

3. Міщенко В.I., Льон I.M. \& Науменкова С.В. () Світові тенденції монетизації економіки Фінанси України. 2017. Вип. 9, 53-74.

4. Нові форми грошей та фінансових активів: становлення, перспективи, ризики: тези I Міжнар. наук.-практ. конф. (29 листопада 2017 р.)/ за заг. ред. Арживітіна С.М. [Електронний ресурс]. Київ: КНЕУ. 2018. 243 с.

5. Grinberg R. Bitcoin: An Innovative Alternative Digital Currency. Hastings Science \& Technology Law Journal. Vol. 4. 2011. P.160-207.

6. Guarda D. Gold or Bitcoin and The New Digital Blockchain Economy? [Electronic resource]. URL: https://www.tradersdna.com/opinion/gold-versus-bitcoin-new-digitalblockchain-economy/.

7. Chuen D.L.K., Deng R. Handbook of Blockchain, Digital Finance and Inclusion. Cryptocurrency, FinTech, InsurTech, Regulation, ChinaTech, Mobile Security. New York:Academic Press, 2017. 1000 p.

8. Dodgson M., Gann D., Wladawsky-Berger I. etc. Managing Digital Money/ M. Dodgson, Gann D., Wladawsky-Berger I. etc. Academy of Management Journal. Vol. 58, No. 2. 2015:doi.org/10.5465/amj.2015.4002. 